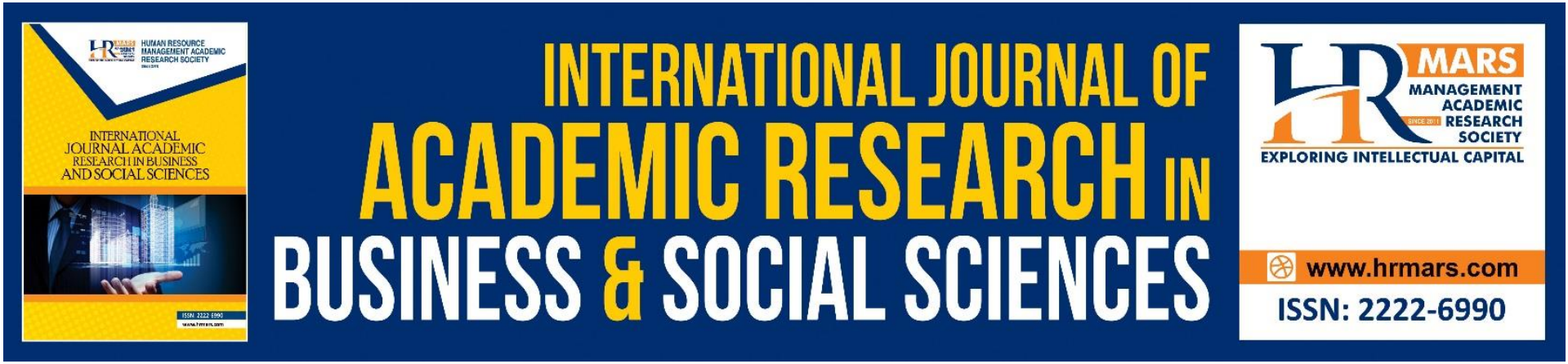

\title{
A Framework of Factors Influencing Performance of Small and Medium Enterprises (SMES) in Tourism Industry During Covid19 Pandemic ERA
}

Hanis Afifah Hamdan Azhar, Wei-Loon Koe, Idris Osman

To Link this Article: http://dx.doi.org/10.6007/IJARBSS/v12-i1/12287

DOI:10.6007/IJARBSS/v12-i1/12287

Received: 09 November 2021, Revised: 12 December 2021, Accepted: 07 January 2022

Published Online: 30 January 2022

In-Text Citation: (Azhar et al., 2022)

To Cite this Article: Azhar, H. A. H., Koe, W.-L., \& Osman, I. (2022). A Framework of Factors Influencing Performance of Small and Medium Enterprises (SMES) in Tourism Industry During Covid19 Pandemic ERA. International Journal of Academic Research in Business and Social Sciences, 12(1), 2244-2256.

Copyright: (c) 2022 The Author(s)

Published by Human Resource Management Academic Research Society (www.hrmars.com)

This article is published under the Creative Commons Attribution (CC BY 4.0) license. Anyone may reproduce, distribute, translate and create derivative works of this article (for both commercial and non0-commercial purposes), subject to full attribution to the original publication and authors. The full terms of this license may be seen at: http://creativecommons.org/licences/by/4.0/legalcode

Vol. 12, No. 1, 2022, Pg. 2244- 2256

http://hrmars.com/index.php/pages/detail/IJARBSS

JOURNAL HOMEPAGE

Full Terms \& Conditions of access and use can be found at http://hrmars.com/index.php/pages/detail/publication-ethics 


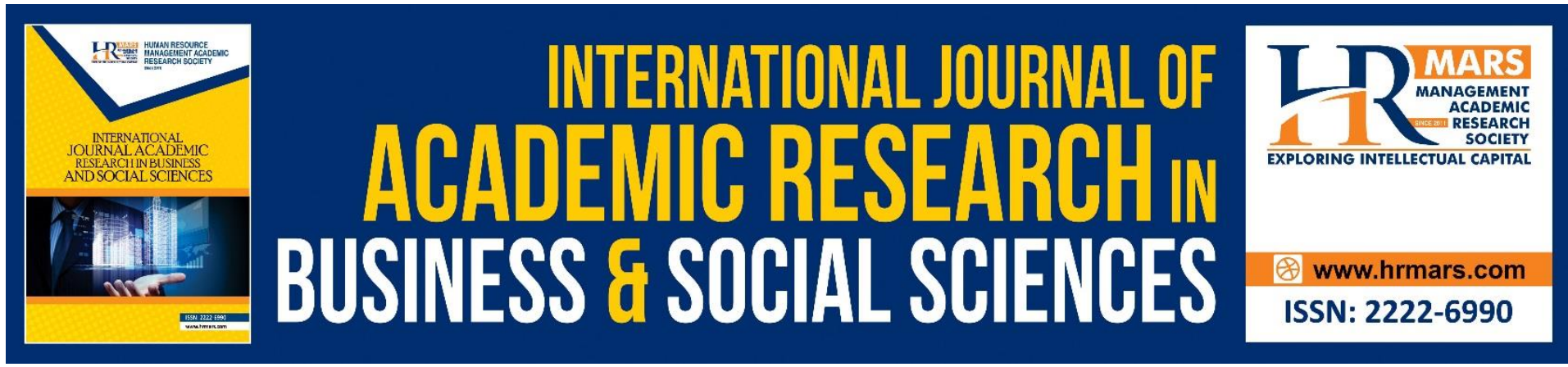

\title{
A Framework of Factors Influencing Performance of Small and Medium Enterprises (SMES) in Tourism Industry During Covid19 Pandemic ERA
}

\author{
Hanis Afifah Hamdan Azhar \\ Universiti Teknologi MARA (UiTM), Cawangan Melaka Kampus Bandaraya Melaka, 110 Off \\ Jalan Hang Tuah, 75350 Melaka, Malaysia \\ Email: hanisafifah87@gmail.com
}

\section{Wei-Loon Koe, Idris Osman}

Universiti Teknologi MARA (UiTM), Cawangan Melaka Kampus Bandaraya Melaka, 110 Off Jalan Hang Tuah, 75350 Melaka, Malaysia.

\begin{abstract}
The Movement Control Order (MCO) and travel restrictions enforced to combat the COVID19 epidemic which have harmed Malaysia's tourist and hospitality industry. Since its emergence in Wuhan, China, it has grown into one of the world's most serious problems. For instance, consider the performance of SMEs in the tourist industry, which has seen a dramatic decline in sales, putting the Visit Malaysia 2020 (VM2020) campaign at danger. Furthermore, cash flow issues, shutdown of operations, layoffs, retrenchment, and weakened businesses' potential for future development were identified as major barriers for SMEs in the tourist industry during this epidemic. Therefore, the goal of this research is to better understand the relationship between stakeholders, CSR, and the performance of small and medium-sized businesses in the tourist industry during the novel COVID-19. This is significant since SMEs account for the majority of existing and new entrants into the tourist sector. To accomplish so, this article used Freeman's stakeholder orientation theory, which includes market orientation (consumer and competitor), employee orientation, and supplier orientation, all of which are influenced by pandemics. We will undertake focused research to investigate how corporate social responsibility (CSR) by Caroll (1991)mediates interactions between stakeholders and SMEs. According to the framework, this analysis could help to boost SMEs tourism in Malaysia during the pandemic and assist managers/owners of SMEs tourism in solving their problems during and after the pandemic. Furthermore, this report emphasised the detrimental influence on Malaysia's tourist and hospitality industries as a result of a catastrophic pandemic disease spreading throughout the world. Despite this, the tourism industry is regarded as the world's fastest-growing economy. Finally, this conceptual analysis will assist the authority in taking further safeguards and determining the appropriate policy to apply in the future. Hence, this framework will contribute valuable evidence for business enterprises in the tourism sector.
\end{abstract}


Keywords: Covid-19, Tourism industry, Small and Medium Enterprises (SME), Stakeholder Theory, Movement Control Order (MCO)

\section{Introduction}

The services sector is a country's most important economic contributor. Not only does it rely on hotels, transportation, and food and beverages, but it also involves the entrepreneurship of the people. It focuses on the traditional, one-of-a-kind nature of local cuisine and crafts, as well as well-known sites. After growth and commodities, tourism is Malaysia's third-largest contributor to GDP. In 2018, this industry provided 5.9\% of GDP growth. The "Visit Truly Asia Malaysia 2020" initiative was created with the purpose of attracting 30 million tourists and creating $\$ 100$ billion in tourism income in Malaysia by 2020.

However, since the extraordinary Covid-19 pandemic, the hospitality and tourist industries have taken a battering. According to the approximate of Malaysian government, the country's GDP fell by 0.8 percent to 1.2 percent last year (RM 10.8 billion to RM 17.3 billion). Inbound international travellers to Malaysia's most popular sites have decreased due to the closure of international borders during the time of movement control order (MCO) that has been in effect since March 18, 2020 (Rahim, 2020). The current Visit Malaysia Year 2020 (VMY2020) promotion has been cancelled, according to the Ministry of Tourism, Arts and Culture. This might have an influence on the government's goal of 30 million visitors during the Visit Malaysia 2020 campaign (Malay Mail, 2020). The Malaysian government has conducted a thorough study of the COVID-19 pandemic because the World Health Organization defined the approach that must be followed in order to prevent the spread from spreading widely. Individuals associated with the tourism sector in Small and Medium Enterprises (SME), in particular, would suffer the most as a result of the revenue decrease, (Nicolaides, 2015). Including owners, employees, competitors, trade associations, unions, customers, activist groups, and the financial community, as well as travel agents, tour operators, media, hotels, taxis, public authorities, and even suppliers, are among the stakeholders, according to the UNWTO. The same source, Peric et al (2014) presents a list of 12 major kinds of stakeholders significant to the firm. In the academic and professional worlds, corporate social responsibility (CSR) is getting a lot of attention. Porter and Kramer's approach stated that the implementation of CSR projects might have an influence on the company's strategy. During this pandemic, CSR initiatives have grown increasingly popular in many industries. It has been identified as a critical topic for company managers to comprehend and manage.

Previous research found that connections between organisations and their stakeholders have a beneficial impact on company performance (Alireza et al., 2020, Jahansoozi, 2006; Peng and Luo, 2000). While some studies show a positive relationship between CSR and firm performance (Maron, 2006; Wu, 2006; Rodgers et al., 2013; Gallardo-Vázquez and SánchezHernández, 2014a), others older claim a negative influence (Boyle et al., 1997; Wright and Ferris, 1998); additionally, further studies are unable to demonstrate the direction or the sign of the relationship (Barnett and Salomon, 2006).

Existing research is limited in that it does not include stakeholders in the performance analysis. To begin with, the prior study had several limitations in that it could not track all corporate governance, CSR, and financial outcomes factors that may impact the analysis. They also have a limited amount of time to do the research. Second, previous research has advised that future studies should include more sorts of stakeholders, such as customers, because they may have a substantial effect on the firm's performance. According to another previous study, companies must contribute to CSR adoption since there is a clear relationship between 
the company's CSR efforts and its stakeholders. Finally, Agyemang and Ansong, (2017) research findings suggested future studies to give treatments that clearly dive into the principles of financial success, stakeholder participation, and CSR activities.

The aforesaid scenario has prompted this study because the influence on both the sales and supply chains is huge and still unpredictable, and the relationship between stakeholders and CSR is remain favourable to tourist performance. As a result, the researcher will be talked on the three key issues in this study. The first is the performance of SMEs in the tourism industry, which have seen a significant reduction in income as a result of the COVID-19 epidemic. Second, despite the fact that CSR implementation in Malaysian SMEs is not as effective as in big or publicly listed businesses in Bursa Malaysia, the adoption of CSR practises by all industries has been increasingly prevalent during this epidemic. Third, taking into account stakeholders in the performance of tourism SME's and the organization's efforts to contribute stakeholders through CSR activities.

As a result, the three main issues described above, namely the relationship between stakeholders, Corporate Social Responsibility (CSR), and the performance of Small and Medium Enterprises (SMEs) in the tourism sector during the COVID-19, can be determined, as small enterprises were viewed as a competitive sector in terms of promoting more job opportunities and improving the socio-economic quality of tourism, (Chernyshev, 2014). Stakeholder theory will focus on establishing relationships and value between firms and their stakeholders, whereas CSR highlights the benefit to society as a whole, (Dmytriyev \& Freeman, 2017). Although the two principles differ in certain ways, they may be used to improve company performance and society as a whole.

At this time, firms should look not only for financial performance but also for society's benefit and the welfare of their stakeholders, thence, SME owner/ manager needs to perform his/her role effectively to maintain and develop the position of the firm in the market and generate legitimate income for the stakeholders and the business itself. The presence of CSR in this conceptual study will further help the authority to take precautions and best policy to be implemented in future.

\section{Literature Review}

\section{Small and Medium Enterprise (SME)}

Small and Medium Enterprise Corporation Malaysia (SME Corp. Malaysia) categorised SMEs according to their annual sales turnover or the number of full-time employees. For the manufacturing sector, businesses with a sales turnover of less than RM50 million and less than 200 employees are eligible. SMEs in the services and other industries are businesses with annual sales of less than RM20 million and fewer than 75 employees (SMECorp, 2019). In 2016, SMEs accounted for 98.5 percent of all business establishments across all economic sectors in Malaysia, 36.6 percent of GDP, and 65.3 percent of employment. Because of the large number of SMEs that have established themselves in the market, any business or economic downturn would undoubtedly affect a wide range of industries as well as national economic growth. Small business performance, on the other hand, is defined as a company's ability to produce employment and luxury via the establishment, survival, and sustainability of a firm (Sandberg et al., 2002).

\section{SMEs Business Activities in the Hospitality and Tourism Industry}

Since the formation of the Tourist Development Corporation (TDC) in 1972, the Hospitality and Tourism Industry (HTI) has been recognized as one of Malaysia's main economic sectors, 
Set (2013). Local eateries that cater to visitor demands; housing in the form of homestays, longhouses, budget hotels, and boutique hotels; transportation; and other essentials are among the SME enterprises in the hospitality and tourism industry. (Sulaiman Sajilan et al., 2016). (Othman and Rosli, 2011) classify tourist business activities into four groups: (1) food and lodging services, (2) retail and souvenirs, (3) travel agents, transportation, and sport, and (4) those that do not fall into the preceding categories. According to Main and Morrison (2002), tourism SMEs are typically run by their owners, who are often married couples. This type of family business is known as a "copreneur".

According to the Malaysian SME Corp, the services sector is also expanding, accounting for more than $60 \%$ of Malaysian SMEs' Gross Domestic Product (GDP) (2014). Malaysia's government's continuing efforts to develop the tourist sector have a positive impact on the operations of SMEs in the tourism industry. This is because there are many chances for SMEs to grow in the hospitality and tourist industries due to the modest amount of start-up capital required, and the barriers to entry appear to be very low (UNESCAP, 2005). The tourist industry's SMEs will have a significant influence on Malaysia's economic growth. Malaysia was rated ninth in the world by the United Nations World Tourism Organization in terms of international tourist arrivals (UNWTO).

\section{Stakeholder Theory}

Freeman (1984) defines the Stakeholders as "any group or individual who can affect or affected by the achievement of the organization's objectives"; however, in one of his most recent definitions, he considers them to be "those groups who are vital to the survival and success of the corporation". Stakeholders are categorized in two, which are primary and secondary. In the opinion of Freeman (1984), primary stakeholder or also called internal stakeholder, is categorized as customers, competitors, shareholders/investors, employees, and suppliers, which shows that organizations face a wide variety of stakeholders.

The key aim of stakeholder theory is to protect against detrimental impacts on the tourism sector during this pandemic. According to Freeman (1984), the business's stakeholder focus is the degree to which the organization takes care of the interests of all individuals involved and hence tries to address those interests. Customers, competitors, employees, and suppliers are the subject of this point of view article. This stakeholder orientation is useful for the convergence of SMEs tourism resources and social network tools, as well as for the shared growth of businesses and society. In the end, it would boost company efficiency based on the concepts of (Kramer, 2006). Over the last three decades, stakeholder management has grown to become one of the most important aspects of CSR. As previously stated by Freeman et al (2010) the function of stakeholder theory within CSR is not just to persuade managers to think about the best overall outcome for society, but also to think about how the interests of the company's stakeholders may be met.

\section{Market Orientation and Firm Performance}

Based on previous research (e.g., Kohli and Jaworski 1990; Narver and Slater 1990), market orientation (MO) was defined as an organizational culture that focuses on analysing and acting on customers' demands, predicting and responding to rivals' activities, sharing that data across the business, and taking coordinated action to produce greater customer value. Consumer orientation, rival orientation, and inter-functional teamwork are the three behavioural components of business orientation, according to Narver and Slater (1990). Customer orientation refers to the understanding of target consumers today and in the future 
in order to produce a continual increase in demand for them. Inter-functional collaboration demands the methodical use of capital in order to deliver greater value to target consumers. Competitor orientation includes recognising current and potential competitors, as well as their strengths, limits, and skills. A consumer-oriented business may retain existing consumers by keeping them pleased and loyal, attracting new customers, attaining the required level of growth and market share, and therefore obtaining the desired rate of sales productivity; (Homburg and Pflesser, 2000).

Marketing idea focuses on establishing customer connections, marketers are better positioned to incorporate stakeholder issues into strategic planning. Several academics have investigated stakeholder perspectives of tourism impacts on their communities in the goal of improved understanding, as clients or tourists are also significant stakeholders. They are the major revenue generators for the tourism and entertainment sectors, Belinda's (2008). Most previous research look at the combined impact of corporate orientation and/or stakeholder orientation on outcomes, according to (Vieregge, 2015). In market literature on customer orientation and competitive orientation, there was also a positive influence on organisational performance, according to (Bearden, 2005). The concept also included a tourism component, which was decided by the quantity of tourist arrivals, which would help SMEs become more efficient. It was argued that fulfilling customer requirements and motivating employees to assist customers would increase shareholder value and help fulfil stakeholder interests, (George's, 2003).

\section{Employee orientation and SMEs performance}

Employee orientation refers to a company's aim to address its employees' interests and meet their job demands (Lings et al., 2000; Webster, 1992). Freeman (1984) considers employees to be an important group of stakeholders in big organisations, however Greenley and Foxall (1996) classify employees as non-consumer stakeholders. Companies with a high level of orientation will get trust and respect from their employees, which will eventually lead to higher performance and financial outcomes than others, Bussy and Suprawan (2012). As workers have direct connection with guests, it is vital for the concerned management to understand the elements that impact the employee's performance. Second, in the tourist business, it is the hotel industry employee who guarantees that his visitors are pleased.

According to research on human resource management, gratified employees have higher morale and job motivation, and they will work harder, more productively, and expeditiously (Becker and Gerhart, 1996; Berman et al., 1999), resulting in increased organisational effectiveness (Koys, 2001). Kotter and Heskett (1992) agree with this position on the value of workers, saying that employees are a contributing element to a firm's success. Frontline personnel who provide customer care will serve their clients better if they are pleased with their jobs, resulting in higher levels of customer satisfaction and, inevitably, increased sales (Kotter and Heskett, 1992; Koys, 2001; Webster, 1992). As a result, small and medium-sized firms should guarantee that their employees are involved, according to Juntunen et al. (2010); otherwise, personnel might have a negative impact on the brand and risk its credibility.

\section{Supplier Orientation and Firm Performance}

Suppliers, according to Donaldson and Preston (1995); Clarkson (1995), are as essential as consumers as main stakeholders. If a company's suppliers leave, it will suffer greatly. The conventional zero-sum relationship between a company and its suppliers should be replaced with a long-term partnership built on mutual trust. Firms that maintain stable cooperative 
relationships with a small number of suppliers may outperform those that possess a big number of suppliers.

The travel and tourists sector is often regarded as the best in the world, according to the majority of people. As a result, the composition of the tourism sector is not surprising, as certain elements of tourism, such as housing, transportation, food and beverage firms, leisure companies and enterprises, travel agencies, and tour operators, are key components of the tourist supply chain, according to (Jigu and Călăreţu, 2013). As previously said, there is no one entity in the tourist sector; nevertheless, the combination of multiple sectors includes main providers such as destination attractions, all modes of transportation, service, and the lodging business. Primary suppliers are also involved in the case of secondary suppliers.

Suppliers and other business relationships are interconnected, with one's success influencing the others. Poor supplier selection leads to significant challenges, and repeated sourcing issues result in long-term issues that harm your business. Financial and economic losses, as well as a damaged image and unfavourable press, are all part of this, (Boer et al., 2001). In order to develop long-term partnerships, a balance of control between the parties, as well as continuity, is required to form cooperative buyer-supplier relationships, (Spekman et al., 1998).

\section{The mediating role of Corporate Social Responsibility (CSR)}

Caroll (1991) proposed a fundamental definition of CSR as a concept that combines ethical, technical, discretionary, business, and legal anticipation of human communities to commercial organisations as a commitment not just to business but also to social welfare as a whole, in light of CSR views. In this context, the presence of CSR is dependent on a company's obligation to consider the wellbeing and beneficial commitment of society through legal, economic, and positive business implementation activities that could benefit various stakeholders, such as business professionals, clients, staff, vendors, shareholders, and various community groups, as well as the environment.

Previous research on CSR in tourism and hospitality has found that the lens used to study the procedure is frequently dictated by the motives for studying the procedure, which can range from CSR as a tool to increase corporate income, boost political efficiency, or increase transparency for stakeholders to CSR as a way to study decision-making ethics. CSR influences the emotive aspect of a business's image, whereas brand loyalty influences the practical image, (Martnez et al., 2014). Corporate social responsibility may be used by tourism companies to promote economic growth, cultural appreciation, environmental conservation, efficient services, live services, and organisational efficiency. This is because the CSR tourism industry will have an impact on a wide range of stakeholders. According to Freeman (1994), CSR engagement will create links among various groups of stakeholders, resulting in improved company performance, according to the stakeholder idea. This plan will be beneficial to the company's prosperity as well.

CSR is a major contributor to businesses' balanced growth, generating wealth, and creating values that can be reinvested to produce economic growth that benefits society as a whole, (Farrington et al., 2017). According to research, tourism companies can distribute scarce capital to improve social welfare, and their attention to shareholder and other stakeholder preferences and requirements (including employees, customers, local populations, and government) has a significant impact on employee attitudes, motivation, and retention, (Supantia and Butcher, 2019). 
In brief, CSR frequently seeks to assist mankind or anybody other than organisations and companies that are influenced by their social policies and practises. CSR is not a required procedure, but rather a way to voluntarily comply with a variety of rules that benefit both society and the business that implements them. On the grounds of this, SME management should incorporate social responsibility practises into their social goals and use them as a strategic tool to help businesses manage expenses, improve their business image, retain qualified employees, and achieve financial success in the long run, according to (Turyakira et al., 2014).

Based on the above discussion, the following model and hypotheses were recommended:

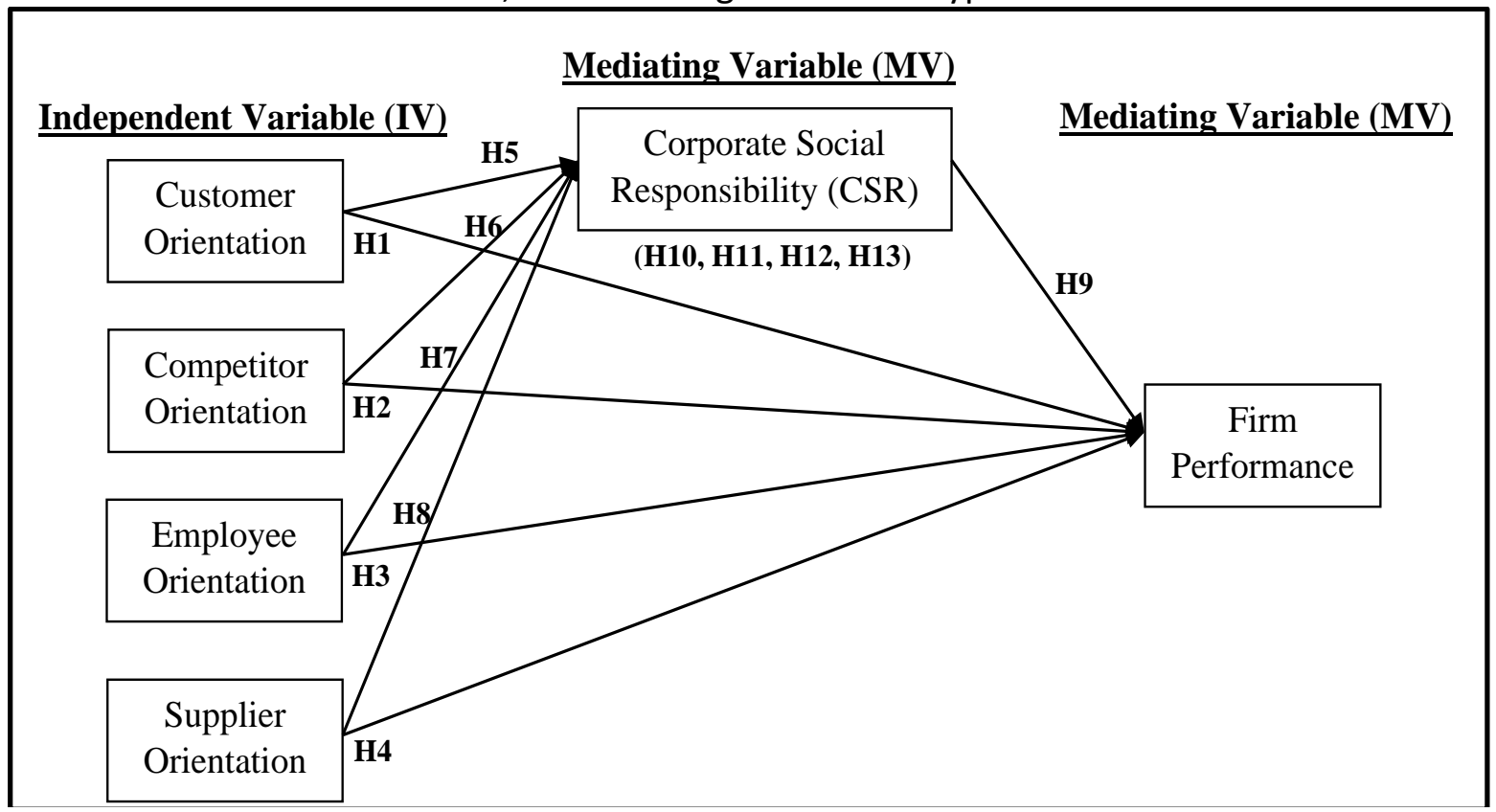

Figure 1: The Proposed Framework

Hypotheses

$\mathrm{H} 1$ : There is a significant relationship between customer orientation and SMEs performance. $\mathrm{H} 2$ : There is a significant relationship between competitor orientation and SMEs performance.

H3: There is a significant relationship between employee orientation and SMEs performance.

$\mathrm{H} 4$ : There is a significant relationship between supplier orientation and SMEs performance.

$\mathrm{H} 5$ : There is a significant relationship between customer orientation and CSR.

H6: There is a significant relationship between competitor orientation and CSR.

$\mathrm{H7}$ : There is a significant relationship between employee orientation and CSR.

$\mathrm{H} 8$ : There is a significant relationship between supplier orientation and CSR.

H9: There is a significant relationship between CSR and SME performance.

H10: CSR mediates the relation between customer orientation and SME performance.

H11: CSR mediates the relation between competitor orientation and SME performance.

H12: CSR mediates the relation between employee orientation and SME performance.

H13: CSR mediates the relation between supplier orientation and SME performance.

\section{Conclusion and Expected Contributions}

Beyond the importance of the tourism contribution to the economic development, the goal of this study was to examine the relationship between Stakeholder orientation, CSR and the 
performance of SME in tourism sectors during the pandemic of Covid-19. We also seek also to investigate the mediating effect of CSR between stakeholder orientation and firm performance. To justify the selection of the stakeholder and CSR practices as factors affecting tourism SMEs performance, we referred to the theoretical frameworks such as stakeholder theory and Carroll's four-part concepts. In the stakeholder theory it consisted of customer, competitor, employee and supplier orientation as independent variable. Whereas, Economic, Legal, Ethical \& Philanthropic are the components of Carroll's CSR Pyramid which will further posited to intervened the relationship.

Based on the findings of a literature analysis of the tourist sector, SMEs' business success is hugely influenced by internal and external variables, including financial and non-financial metrics. Similarly, the impact on stakeholder orientation and small business performance in tourism sectors is well recognised in the literature especially during this pandemic. Tourism generates economic possibilities for small entrepreneurs in a variety of tourism-related business activities, including local agricultural, manufacturing, service, and constructionrelated industries, due to low start-up costs and low barriers to entry. The most noticeable are business prospects in tourism-related services, such as lodging, food outlets, tourist agents or guides, shopping, and sport facilities, because both local and international travellers require a variety of services during their stays on the islands.

SMEs play a leading role in the Malaysian economy. Therefore, investigation of their performance is a worthwhile scholarly endeavor. To overcome the tourism and hospitality industry's downfall, both parties (Malaysian government and business owner) must aggressively play the roles of SME's survival strategies. The Malaysian government should assist all people who have been harmed by the covid-19 outbreak. Otherwise, if the situation stays unchanged, these industries will not be able to thrive for very long. With the government's help, they can address the problem of Covid-19's present position, which has such a catastrophic impact. Every firm and sector will need time to get back on track to success.

As for the business owner of the service sectors, they should also have strategies of their own such as taking part of their firm in CSR activities as CSR can be a "win-win" option for both communities and organizations in terms of gaining long-term benefits. Over the years, a variety of studies have investigated the effect of CSR on a number of organizational outcomes, such as brand equity, Nguyen and Oyotode (2015), business success, Becchetti, et al (2007), and firm performance, (Peloza, 2006). According to the stakeholder principle, Freeman (1994), CSR engagement will reinforce relationships between various groups of stakeholders, such an approach will have beneficial impacts on the performance of the business. Similarly, Jo and Harjoto (2011) contend that CSR involvement by managers is used to resolve stakeholders' conflicts and thereby maximize equity resources. In this study, we focus on Carroll's four-part concepts of CSR which has been the most long-lasting and often quoted in the literature was originally stated the primary definition as a concept involving ethical, economic, discretionary, corporate, and law advances in human communities for business firms and also the general social welfare in which it will positively influence on business performance.

This model will help in identifying some expect that influence the sustainability of the performance to society's especially to owner/ manager of SMEs tourism sector during this COVID-19 pandemic in the future for their venture in the global market. Thus, owner/ manager of SME that apply the recommended approach derived from the results of this study will gain better performance to their firms. As for administrators, they will be guided on what 
should be emphasized by the owner/manager in the SMEs tourism to improve the performance of their firms. Lastly for the researcher, the investigation will uncover critical areas in the context of stakeholders, Corporate Social Responsibility (CSR) and SMEs tourism performance during this COVID-19 pandemic that many researchers could not explore.

In this present study we, therefore, attempt to explore whether the contributions of CSR are responding to customer, competitor, employee and supplier orientation with most urgent actions such as creating awareness, and other in-kind supports as well as contributions of time and expertise as the entire world is now grappling with the effects of the COVID-19 pandemic in businesses, particularly in SME tourism and other small businesses that are related.

\section{References}

Agyemang, O. S., \& Ansong, A. (2017). Corporate social responsibility and firm performance of ghanaian SMEs. Journal of Global Responsibility, 8(1), 47-62. https://doi.org/10.1108/jgr-03-2016-0007

Barnett, M. L., \& Salomon, R. M. (2006). Beyond dichotomy: The curvilinear relationship between social responsibility and financial performance. Strategic Management Journal, 27(11), 1101-1122. https://doi.org/10.1002/smj.557

Becchetti, L., Ciciretti, R., \& Hasan, I. (2009). Corporate social responsibility and shareholder's value: An event study analysis. SSRN Electronic Journal, 1-33. https://doi.org/10.2139/ssrn.928557

Becker, B., \& Gerhart, B. (1996). The impact of human resource management on organizational performance: Progress and prospects. Academy of Management Journal, 39(4), 779-801. https://doi.org/10.5465/256712

Berman, S. L., Wicks, A. C., Kotha, S., \& Jones, T. M. (1999). Does stakeholder orientation matter? The relationship between stakeholder management models and firm financial performance. Academy of Management Journal, 42(5), 488-506. https://doi.org/10.5465/256972

Carroll, A. B. (1991). The pyramid of corporate social responsibility: Toward the moral management of organizational stakeholders. Business Horizons, 34(4), 39-48. https://doi.org/10.1016/0007-6813(91)90005-g

Chernyshev, M. I. (2014). Measuring employment in the tourism industries - guide with best practices [E-book]. World Tourism Organization (UNWTO) and the International Labour Organization (ILO). https://doi.org/10.18111/9789284416158

Clarkson, M. E. (1995). A stakeholder framework for analyzing and evaluating corporate social performance. Academy of Management Review, 20(1), 92-117. https://doi.org/10.5465/amr.1995.9503271994

de Boer, L., Labro, E., \& Morlacchi, P. (2001). A review of methods supporting supplier selection. European Journal of Purchasing \& Supply Management, 7(2), 75-89. https://doi.org/10.1016/s0969-7012(00)00028-9

de Bussy, N. M., \& Suprawan, L. (2012). Most valuable stakeholders: The impact of employee orientation on corporate financial performance. Public Relations Review, 38(2), 280287. https://doi.org/10.1016/j.pubrev.2011.11.006

Donaldson, T., \& Preston, L. E. (1995). The stakeholder theory of the corporation: Concepts, evidence, and implications. Academy of Management Review, 20(1), 65-91. https://doi.org/10.5465/amr.1995.9503271992 
Dzulkifly, D. (2020). Muhyiddin: Tourism industry hit hardest by covid-19, faces RM3.37b loss. Malaysia I Malay Mail. Retrieved February 16, 2021, from https://www.malaymail.com/news/malaysia/2020/03/13/muhyiddin-tourismindustry-hit-hard-by-covid-19-to-lose-rm3.37b-while-gdp-s/1846323

Farrington, T., Curran, R., Gori, K., O'Gorman, K. D., \& Queenan, C. J. (2017). Corporate social responsibility: Reviewed, rated, revised. International Journal of Contemporary Hospitality Management, 29(1), 30-47. https://doi.org/10.1108/ijchm-05-2015-0236

Freeman, R. E., \& Dmytriyev, S. (2017). Corporate social responsibility and stakeholder theory: Learning from each other. SYMPHONYA Emerging Issues in Management, 2(1), 7-15. https://doi.org/10.4468/2017.1.02freeman.dmytriyev

Gallardo-Vázquez, D., \& Sanchez-Hernandez, M. I. (2014). Measuring corporate social responsibility for competitive success at a regional level. Journal of Cleaner Production, 72, 14-22. https://doi.org/10.1016/j.jclepro.2014.02.051

Inus, K. (2020, February 12). Malaysia has lost RM3 bil in tourism business due to covid-19 to date. The Star. Retrieved March 22, 2021, from https://www.thestar.com.my/news/nation/2020/02/12/tourism-industry-hassuffered-rm3bil-loss-due-to-covid-19

Jahansoozi, J. (2006). Organization-stakeholder relationships: Exploring trust and transparency. Journal of Management Development, 25(10), 942-955. https://doi.org/10.1108/02621710610708577

Jalali, A., Jaafar, M., \& Ramayah, T. (2020). Organization-stakeholder relationship and performance of iranian SMEs. International Journal of Islamic and Middle Eastern Finance and Management, 13(3), 417-436. https://doi.org/10.1108/imefm-11-20180407

Jo, H., \& Harjoto, M. A. (2011). Corporate governance and firm value: The impact of corporate social responsibility. Journal of Business Ethics, 103(3), 351-383. https://doi.org/10.1007/s10551-011-0869-y

Juntunen, M., Saraniemi, S., Halttu, M., \& Tähtinen, J. (2010). Corporate brand building in different stages of small business growth. Journal of Brand Management, 18(2), 115133. https://doi.org/10.1057/bm.2010.34

Karim, W., Haque, A., Anis, Z., \& Ulfy, M. A. (2020). The movement control order (MCO) for COVID-19 crisis and its impact on tourism and hospitality sector in malaysia. International Tourism and Hospitality Journal, 3(2), 1-7. https://doi.org/10.37227/ithj2020-02-09

Kohli, A. K., \& Jaworski, B. J. (1990). Market orientation: The construct, research propositions, and managerial implications. Journal of Marketing, 54(2), 1-18. https://doi.org/10.2307/1251866

Kotter, J. P., \& Heskett, J. L. (1992). Corporate culture and performance. Amsterdam University Press.

Koys, D. J. (2001). The effects of employee satisfaction, organizational citizenship behavior, and turnover on organizational effectiveness: A unit-level, longitudinal study. Personnel Psychology, 54(1), 101-114. https://doi.org/10.1111/j.1744-6570.2001.tb00087.x

Luk, C. L., Yau, O. H., Tse, A. C., Sin, L. Y., \& Chow, R. P. (2005). Stakeholder orientation and business performance: The case of service companies in china. Journal of International Marketing, 13(1), 89-110. https://doi.org/10.1509/jimk.13.1.89.58536

Malaysia: National Entrepreneur \& SME Development Council. (n.d.). Guideline for SME definition. SME Corp. Malaysia. Retrieved April 24, 2021, from 
https://www.smecorp.gov.my/images/pdf/2021/Guideline_on_SMEDefinition_Updat ed_Sept2020_Final.pdf

Marom, I. Y. (2006). Toward a unified theory of the CSP-CFP link. Journal of Business Ethics, 67(2), 191-200. https://doi.org/10.1007/s10551-006-9023-7

Martínez, P., Pérez, A., \& del Bosque, I. R. (2014). CSR influence on hotel brand image and loyalty. Academia Revista Latinoamericana de Administración, 27(2), 267-283. https://doi.org/10.1108/arla-12-2013-0190

McWilliams, A., \& Siegel, D. (2001). Corporate social responsibility: A theory of the firm perspective. Academy of Management Review, 26(1), 117-127. https://doi.org/10.5465/amr.2001.4011987

Moorthy, M. K., Tan, A., Choo, C., Wei, C. S., Ping, J. T. Y., \& Leong, T. K. (2012). A study on factors affecting the performance of SMEs in malaysia. International Journal of Academic Research in Business and Social Sciences, 2(4), 224-239.

Morrison, A., \& Teixeira, R. (2004). Small business performance: A tourism sector focus. Journal of Small Business and Enterprise Development, 11(2), 166-173. https://doi.org/10.1108/14626000410537100

Nguyen, C. N., \& Oyotode, R. (2015). The moderating effect of marketing capabilities on the relationship between changes in CSR perceptions and changes in brand equity. International Management Review, 11(1), 17-68.

Nicolaides, P. A. (2015). Tourism stakeholder theory in practice: Instrumental business grounds, fundamental normative demands or a descriptive application? African Journal of Hospitality, Tourism and Leisure, 4(2), 1-27.

https://executivetrainingmile.files.wordpress.com/2014/05/stakeholders.jpg?w=1008

Othman, P., \& Rosli, M. M. (2011). The impact of tourism on small business performance: Empirical evidence from malaysian islands. International Journal of Business and Social Science, 2(1), 11-21.

Peloza, J. (2006). Using corporate social responsibility as insurance for financial performance. California Management Review, 48(2), 52-72. https://doi.org/10.2307/41166338

Peng, M. W., \& Luo, Y. (2000). Managerial ties and firm performance in a transition economy: The nature of a Micro-Macro link. Academy of Management Journal, 43(3), 486-501. https://doi.org/10.5465/1556406

Perić, M., ĐUrkin, J., \& Lamot, I. (2014). Importance of stakeholder management in tourism projects: Case study of istria inspirit project. Tourism Hospitality Management, 273286. https://www.researchgate.net/publication/337111163

Rahim, R. (2020). Covid-19: Tourism ministry cancels visit malaysia year 2020. The Star. Retrieved February 15, 2021, from

https://www.thestar.com.my/news/nation/2020/03/18/covid-19-tourism-ministrycancels-visit-m039sia-year-2020

Ramayah, T., Samat, N., \& Lo, M. (2011). Market orientation, service quality and organizational performance in service organizations in Malaysia. Asia-Pacific Journal of Business Administration, 3(1), 8-27. https://doi.org/10.1108/17574321111116379

Rodgers, W., Choy, H. L., \& Guiral, A. (2013). Do investors value a firm's commitment to social activities? Journal of Business Ethics, 114(4), 607-623. https://doi.org/10.1007/s10551-013-1707-1

Sajilan, S., Tehseen, S., \& Adeyinka-Ojo, S. (2016). A conceptual framework of the impact of entrepreneurial competencies on small and medium enterprises business performance 
in the malaysian hospitality and tourism industry. Review of Integrative Business and Economics Research, 5(2), 47-61.

Sandberg, K., Vinberg, S., \& Pan, Y. (2002). An exploratory study of women inmicroenterprise: Owner perceptions of economic policy in a rural municipality:gender-related differences. CD-Proceedings of 12th Nordic Conference on Small Business Research, 114.

Segal, S., \& Gerstel, D. (2020a, March 10). The global economic impacts of COVID-19. Global S\&T Development Trend Analysis Platform of Resources and Environment. http://119.78.100.173/C666/handle/2XK7JSWQ/250233

Segal, S., \& Gerstel, D. (2020b, April 30). Breaking down the g20 covid-19 fiscal response. Global S\&T Development Trend Analysis Platform of Resources and Environment. Retrieved May 19, 2020, from http://resp.Ilas.ac.cn/C666/handle/2XK7JSWQ/250014

Spekman, R. E., Kamauff, J. W., \& Myhr, N. (1998). An empirical investigation into supply chain management: A perspective on partnerships. Supply Chain Management: An International Journal, 3(2), 53-67. https://doi.org/10.1108/13598549810215379

Supanti, D., \& Butcher, K. (2019). Is corporate social responsibility (CSR) participation the pathway to foster meaningful work and helping behavior for millennials? International Journal of Hospitality Management, 77, 8-18.

https://doi.org/10.1016/j.ijhm.2018.06.001

Jlgu, G., \& Călăreţu, B. (2013). Supply chain management performance in tourism continental hotels chain case. Amfiteatru Economic Journal, 15(33), 103-115.

Turyakira, P., Venter, E., \& Smith, E. (2014). The impact of corporate social responsibility factors on the competitiveness of small and medium-sized enterprises. South African Journal of Economic and Management Sciences, 17(2), 157-172. https://doi.org/10.4102/sajems.v17i2.443

Ward, S., Girardi, A., \& Lewandowska, A. (2006). A Cross-National validation of the narver and slater market orientation scale. Journal of Marketing Theory and Practice, 14(2), 155167. https://doi.org/10.2753/mtp1069-6679140205

Webster, F. E. (1992). The changing role of marketing in the corporation. Journal of Marketing, 56(4), 1-17. https://doi.org/10.2307/1251983

Wright, P., \& Ferris, S. P. (1997). Agency conflict and corporate strategy: The effect of divestment on corporate value. Strategic Management Journal, 18(1), 77-83. https://doi.org/10.1002/(SICI)1097-0266(199701)18:1\%3C77::AIDSMJ810\%3E3.0.CO;2-R

Wu, M. L. (2006). Corporate social performance, corporate financial performance, and size: A Meta-Analysis. Journal of American Academy of Business, 8(1), 163-171.

Yau, O. H., Chow, R. P., Sin, L. Y., Tse, A. C., Luk, C., \& Lee, J. S. (2007). Developing a scale for stakeholder orientation. European Journal of Marketing, 41(11/12), 1306-1327. https://doi.org/10.1108/03090560710821198 